\title{
Perceived Organizational Support and Psychological Employment Contract Breach: A Proposed Model on the Mediating Effect of Trust
}

\author{
Shakur Faruk, Zulkiflee Daud, Saiful Azizi Ismail
}

\begin{abstract}
The present paper presents a proposed model and examines the literature review of trust on the relationship between perceived organizational support and psychological employment contract breach. Most of the previous study on psychological contract were conducted in the Asian and western world and very scanty in African countries. Hence, psychological employment contract breach, particularly in Nigeria which is a developing country, has been discussed. Mixed results was found regarding the relationship between perceived organizational support, trust and psychological employment contract breach. Conclusively, suggestion was made for future research.
\end{abstract}

Index Terms: Nigeria, perceived organizational support, review of literature, trust and psychological employment contract breach.

\section{INTRODUCTION}

Psychological contract plays a crucial role in assisting to defining and understanding contemporary employment relationship in an organization because it is a conceptual vehicle that define expectation that employee-employer have for one another [1], [2] and the level at which the organization ensures the fulfilment of employment psychological contract plays a crucial role in strengthening the relationship between and employee in work place [3], [4]. Employee perception has a great influence on how they view their employer and the organization as a whole.

A contract is a set of rules that defines the mutual obligations and rights which are essential to manage an exchange relationship [5] and employment contract, involves the term of an exchange regarding the quantity of employees time in exchange for certain amount i.e. wage or salary [6]. Hence, employees always have the expectation that the employer should adhere to the terms and conditions of employment by fulfilling it accordingly as it has large impact on the workers perception in work place. Perhaps, when there is an unfair treatment by employer, employees would regularly observe that the employer has failed to sufficiently meet up its promises, and therefore, develop a feeling that their contractual agreement with the organization has been breached [7], [8] which can result to

Revised Manuscript Received on July 10, 2019.

Shakur Faruk, School of Business Management, Othman Yeop

Zulkiflee Daud, School of Business Management, Othman Yeop Abdullah Graduate School of Business, Universiti Utara Malaysia. Abdullah Graduate School of Business, Universiti Utara Malaysia. Abdullah Graduate School of Business, Universiti Utara Malaysia.

Saiful Azizi Ismail, School of Business Management, Othman Yeop

high emotional effects, such as feelings of betrayal and frustration [9]-[11].

Despite the importance of psychological contract to an employee in an organization, it is confronted with issues of breach in Nigeria educational sector, knowing fully well that globally, Universities are considered as the citadel of academic excellence, knowledge, source of intellectualism and above all, the suitable environment for the grooming future leaders [12] and lecturers serves as key factor in achieving the aims and objectives of any university system [13].

While, the advanced nations have enormous and sound higher educational institutions thereby seeing education as governance, the under-developed countries remain at the basic foundation and incessantly lack the value for the need of taking it with utmost importance [14], [15] as can be found in Nigeria public universities where series of employment contract were breached by the employer.

More so, when employees in organization perceived that the employer has failed to adequately fulfil its promised responsibilities, they develop the feelings that their employment contract has been breached, 8 and it is on this note that the study of [16] stated that employment contract breach by employer is positively related to employee feelings of discrimination in the organization.

Furthermore, when employer fails to fulfil their promises to employee, trust is negatively affected [17]. This is because employee will no longer have confidence on the employer due to perceived disappointment on psychological contract, knowing fully well that distrust over employment contract may direct to dispute on employment contract. More so, perceived organizational support is one of the factor that influences psychological contract breach [18] and psychological contract itself is based on the level of trust in the other party's integrity; that's is, a belief that the other party will meet up to their obligation and promises [19].

The objective of the present research is to review literatures on perceived organizational support, trust and psychological employment contract breach in Nigeria public universities. The article is organized in following sequence. Background of the study, problem statement, Review of previous literatures, conclusions and suggestion for future research.

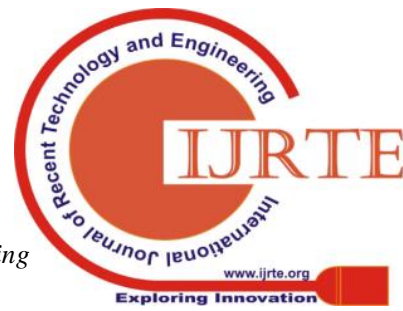




\section{PERCEIVED ORGANIZATIONAL SUPPORT AND PSYCHOLOGICAL EMPLOYMENT CONTRACT BREACH: A PROPOSED MODEL ON THE MEDIATING EFFECT OF TRUST}

\section{PROBLEM STATEMENT}

Fulfilment of psychological contract is paramount because when organization adhere strictly to promises made to employee, the later tend to put in their best for the organization in terms of both behaviours and attitude [20]. As this singular act encourages the employees regarding the honour and regards being attached to them by their employer. The need to ensure that psychological contract is maintained on employees in the academia is of utmost importance as lecturers serves as the key element of steering the affairs of the institutions [13]. Because through effective psychological contract, wide range of problems such as feeling of betrayal, deviancy, distrust, negative attitude at work place among others is reduced or halt [9]-[11], [21], [22].

Furthermore, while most of the studies of psychological contract breach is conducted in developed world such as Asia and European countries, less attention is attached to it in developing and underdeveloped countries and Nigeria to be specific [23], [4] therefore, it is important to examine psychological contract breach in African countries and Nigeria to be specific [24].

Similarly, for an organization to always be Successful, it must try to keep their employees satisfied and motivated in carrying out their jobs [25] knowing fully well that In any educational settings, lecturers are regarded to be the pillars of society due to their great task in training and educating students to become future leaders [26]. Therefore, when they are psychologically stable with their jobs, they tend to be satisfied, innovative, creative, and initiative in performance [27], [28]. And this is missing in Nigeria public university as promotions are being delayed and sacking of lecturers without following due process [13], [29]-[32]. All these problems influences the perception of employee in the organisation thereby perceiving psychological employment contract breach. It was stated that Nigeria is faced with series of challenges resulting to industrial action which requires serious government/employer commitment [33].

It is based on this observation that perceived organizational support has an influence on psychological employment contract breach in Nigeria public universities. Based on previous studies, perceived organizational support breach [34]. Similarly, in [35] in their study found that perceived organizational support influences psychological contract breach. While contrarily, some research did not found any notable direct influence between perceived organizational support and psychological contract breach [36], [37].

Furthermore, studies also revealed trust is another factor that significantly influences psychological contract breach [38] while contrarily, some current studies revealed otherwise [39]. Based on this contradictory results, there is an evidence of existing gap in literature concerning the relationship between perceived organizational support, trust, and psychological employment contract breach. Therefore, the present study will attempt to fill this existing gap, considering the problem of the study, the objective will be achieved accordingly. has an influence on psychological employment contract

\section{DISCUSSION \& RESULTS}

\section{Psychological Employment Contract Breach Defined}

Psychological contract in an organization was viewed by researchers as being established via model of unconscious motives, needs and expectations [40] because employees have expectations in mind which is expected to be fulfilled by employer as promised. Therefore, psychological contract is an "individual's beliefs regarding the terms and conditions of a reciprocal exchange agreement between that focal person and another party" [19]. Hence, serves as mental perception that binds the employer and employee terms and exchange agreements [7]. But it transformed to psychological contract breach due to "failure of organizations or employer to respond to an employee's contribution in ways the individual believes they are obligated to do so" [19], [41]. Other scholars viewed it as "the cognitions that one's organization has failed to meet one or more obligations within one's psychological contract in a manner that commensurate with one's contributions" [9].

Furthermore, perceived obligations that are expected to be reciprocated by employer to employee in an organization may include the following; compensation, job security and career growth opportunities which is transacted in exchange for employee contributions [7]. Researchers has elaborated that perceived breach in a work place have negative impact for both employees and employer including reduced commitment, low organizational citizenship behaviors, reduced job satisfaction and increased negative perception towards the organization, with an intention to quit [2]. This is because employee tend to loose trust and confidence in employer leading to development of negative attitudes that may affect employee input in an organization.

In addition, in [42] stated that psychological contract breach has various constituents which are as follows: Delay in fulfilling promises made on the part of employer or organization, providing or delivering below what was promised between employer and employee, providing promises differently from the initial type or form of stated agreement, unfairness where what individual receives is seeming as being fewer than or dissimilar from what others in the same positions are getting which signifies discrimination among employee, and reciprocal inequality where an individual observes that their input outweighs what the employer is providing them in return as compensation for job done, generating to different views of the initial terms of employment contract by which an employee was hired.

\section{Perceived Organizational Support and Psychological Employment Contract Breach}

Several studies examined the relationship between Perceived organizational support and Psychological employment contract breach, however, the result of the research are contradictory. Based on the opinion of different studies, perceived organizational support is basically centered on employees' perception regarding how the and Engin IJRTE \& Sciences Publication 
employer values their contribution to the organization and showing concern about their well-being [43]-[45]. When employees are involved in decision making, sharing of information, given recognition, training and selfmanagement teams, it enhances perceived organizational support leading to employee job satisfaction, loyalty, job commitment and performance [46], [47]. Hence, employers should ensure that they try as much as possible to grant the promises made to employees, as this singular act would strengthen the trust and confidence between them.

More so, researchers consider the fact that perceived organizational support influences psychological employment contract breach [35], [48]. Other studies revealed that there is an encouraging impact of the perceived organizational support on psychological employment contract breach [37], [49]. While on the other hand, some findings revealed that there is weak or insignificant relationship between perceived organizational support and psychological employment contract breach [50], [51] as this has resulted to contradictory result based of previous studies and review of literatures respectively.

Trust and Psychological Employment Contract Breach. According to [52], it defined Trust as "one's expectations, assumptions, or beliefs about the likelihood that another's future actions will be beneficial, favourable, or at least not detrimental to one's interests". It is an important variable that strengthen employee -employer relationship at long run [53]. Studies have revealed that employees perception of employment contract breach can be reduced or overcome by trust as it decreases their frustration that may lead to crises in place of work [53]-[55], because it is built on employer employee mutual obligation of exchange relationship over time [56]. Maintaining trust between employer and employee goes a long way in enhancing stated organizational aims and objectives in an effective and efficient manner. This is because employees would be encouraged to put in their best for the organization.

Previous studies have shown that trust is positively related to psychological employment contract breach and results indicated that there is significant relationship between trust and psychological contract breach [38], [53], [55]. More so, other literature review resulted in negative influence regarding the relationship between trust and psychological employment breach [39], [57] which signifies mixed result and inconsistencies in results.

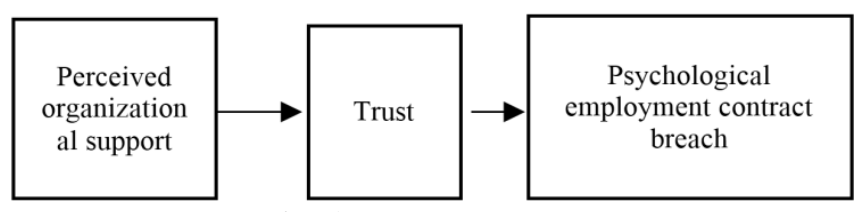

Fig. 1: Proposed model

\section{Proposed Conceptual Model}

Going by aforementioned, the purpose of this article presents a model which shows the relationship between perceived organizational support, trust and psychological employment contract breach. The model is derived from the review of previous literatures and it shows the mediating influence of trust on perceived organizational support and psychological employment contract breach. The arrow depicts direction of relationship that exist among the variables. The proposed model reveals that the relationship perceived organizational support and psychological employment contract breach is contingent on the mediating variable which is trust. More so, the proposed model signifies that trust has an influence on psychological contract and psychological employment contract breach.

\section{Proposed Methodology}

From the previous literatures, it show that studies that were conducted on the variable made use of survey research design and the unit of analysis is the organization using employees of the organization as respondents so as to fill the questionnaires by providing answers accordingly. This signifies the usage of questionnaire as an instrument for data collection for the purpose of reaching maximum number of respondents which is suitable for the study when compared to interview were just a few respondents can be reached. Hence, the use of survey and questionnaire was also proposed in the present study. The questionnaires would be administered to academic staff of 13 Nigerian public universities in the North western region of the country. This is because the issue concerns them and the study tries to see ways of improving perceived breach among lecturers of these institutions. There is total number of 7,062 lecturers that are employees of these institution would be selected through table size by [58] that will result to sample size of 367. Hence, stratified random sampling would be used for selection.

\section{CONCLUSION}

There have been contrary studies on the relationship between perceived organizational support, trust, and psychological employment contract breach. Some researches show positive, significant and or negative relationship among these variables. Considering the contrary nature of studies, therefore, there is the need to investigate the relationship among this variable and with the aim of providing result and recommendation.

\section{REFERENCES}

1. A. M. O'Leary-Kelly, K. E. Henderson, V. Anand, and B. E. Ashforth, "Psychological contracts in a nontraditional industry: Exploring the implications for psychological contract development," Group and Organization Management, 39(3), 2014, pp. 326-360.

2. H. A. Zhao, S. J. Wayne, B. C. Glibkowski, and J. Bravo, "The impact of psychological contract breach on work-related outcomes: A meta-analysis," Personnel Psychology, 60(3), 2007, pp. 647-680.

3. N. Conway, T. Kiefer, J. Hartley, and R. B. Briner, "Doing more with less? Employee reactions to psychological contract breach via target similarity or spillover during public sector organizational change," British Journal of Management, 25(4), 2014, pp. 737 754.

4. S. L. Restubog, T. J. Zagenczyk, P. Bordia, S. Bordia, and G. J. Chapman, "If you wrong us, shall we not revenge? Moderating roles of self-control and perceived aggressive work culture in predicting responses to

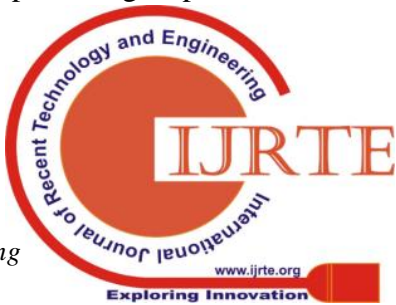




\section{PERCEIVED ORGANIZATIONAL SUPPORT AND PSYCHOLOGICAL EMPLOYMENT CONTRACT BREACH: A PROPOSED MODEL ON THE MEDIATING EFFECT OF TRUST}

psychological contract breach," Journal of Management, 41(4), 2015, pp. 1132-1154.

5. W. Brown, and D. Rea, "The changing nature of the employment contract," Scottish Journal of Political Economy, 42(3), 1995, pp. 363-377.

6. D. I. Levine, How New is the "New Employment Contract"? Evidence from North American Pay Practices. Michigan: WE Upjohn Institute, 2002.

7. D. Rousseau, Psychological Contracts in Organizations: Understanding Written and Unwritten Agreements.

8. G. Topa, and I. Jiménez, "Contract breach and retirement among Spanish adults: A mediated moderation model," Journal of Career Development, 44(4), 2017, 327-343.

9. N. Conway, and R. B. Briner, "A daily diary study of affective responses to psychological contract breach and exceeded promises," Journal of Organizational Behavior: International Journal of Industrial, Occupational and Organizational Psychology and Behavior, 23(3), 2002, pp. 287-302.

10. E. W. Morrison, and S. L. Robinson, "When employees feel betrayed: A model of how psychological contract violation develops," Academy of management Review, 22(1), 1997, pp. 226-256.

11. S. L. Robinson, and E. W. Morrison, "The development of psychological contract breach and violation: A longitudinal study," Journal of organizational Behavior, 21(5), 2000, pp. 525-546.

12. B. L. Philipp, and P. D. Lopez, "The moderating role of ethical leadership: Investigating relationships among employee psychological contracts, commitment, and citizenship behavior," Journal of Leadership and Organizational Studies, 20(3), 2013, pp. 304-315.

13. E. Nwakpu, Letter to the Executive Governor of Ebonyi State on the True Situation of Ebonyi State University and why they are on Strike. Available: www.asuu.underscore.asuus trugle@yahoo.com.

14. A. Usman, and M. A. Ijaiya, "Budgetary allocations and sectoral contributions to economic development in Nigeria," Interdisciplinary Journal of Contemporary Research, 1(10), 2010, pp. 280-297.

15. M. S. Aliyu, Alliance orientation, total quality management and performance of Nigerian public universities: The role of corporate entrepreneurship. $\mathrm{PhD}$ thesis, Kedah: Universiti Utara Malaysia, 2016.

16. R. G. DelCampo, K. M. Rogers, and K. J. Jacobson, "Psychological contract breach, perceived discrimination, and ethnic identification in Hispanic business 2010, pp. 220-238.

17. A. Walker, "Outcomes associated with breach and fulfillment of the psychological contract of safety," Journal of Safety Research, 47, 2013, pp. 31-37.

18. S. Armeli, R. Eisenberge, P. Fasolo, and P. Lynch, "Perceived organizational support and police performance: The moderating influence of socioemotional needs," Journal of Applied Psychology, 83(2), 1998, pp. 288-297.

19. D. M. Rousseau, "Psychological and implied contracts in organizations," Employee Responsibilities and Rights Journal, 2(2), 1989, pp. 121-139.

20. W. H. Turnley, M. C. Bolino, S. W. Lester, and J. M. Bloodgood, "The impact of psychological contract fulfillment on the performance of in-role and organizational citizenship behaviors," Journal of Management, 29(2), 2003, pp. 187-206.

21. M. Fayyazi, and F. Aslani, "The influence of psychological contract breach on employees/deviant workplace behavior; The mediating role of job satisfaction,” Int. J. Econ. Comm. Manag., 3, 2015, pp. 103-142. California: Sage Publications, 1995. professionals," Journal of Managerial Issues, 22(2),

22. G. Brown, C. Crossley, and S. L. Robinson, "Psychological ownership, territorial behavior, and being perceived as a team contributor: The critical role of trust in the work environment," Personnel Psychology, 67(2), 2014, pp. 463-485.

23. K. Kiazad, S. E. Seibert, and M. L. Kraimer, "Psychological contract breach and employee innovation: A conservation of resources perspective," Journal of Occupational and Organizational Psychology, 87(3), 2014, pp. 535-556.

24. A. G. Balogun, T. S. Oluyemi, and O. A. Afolabi, "Psychological contract breach and workplace deviance: Does emotional intelligence matter?" Journal of Psychology in Africa, 28(1), 2018, pp. 8-14.

25. K. Griffin, "Striving for success: A qualitative exploration of competing theories of high-achieving Black college students' academic motivation," Journal of College Student Development, 47(4), 2006, pp. 384-400.

26. M. Li, and M. Bray, "Cross-border flows of students for higher education: Push-pull factors and motivations of mainland Chinese students in Hong Kong and Macau," Higher Education, 53(6), 2007, pp. 791-818.

27. S. Munyengabe, H. Haiyan, Z. Yiyi, and S. Jiefei, "Factors and levels associated with lecturers' motivation and job satisfaction in a Chinese university," Eurasia Journal of Mathematics, Science and Technology Education, 13(10), 2017, pp. 6415-6430.

28. A. M. Usop, D. K. Askandar, M. Langguyuan-Kadtong, and D. A. Usop, "Work performance and job satisfaction among teachers," International Journal of Humanities and Social Science, 3(5), 2013, pp. 245-252.

29. C. N. Ugwuona, "2013 ASUU strike discourses in Nigeria: A critical discourse analysis," Mediterranean Journal of Social Sciences, 7(2), 2016, pp. 435-444.

30. S. Z. Fagbemi, and C. Idoko, FG owes varsities N623bn - ASUU demands immediate release, payment of salaries, pension to douse tension. 2016, Available: https://www.tribuneonlineng.com/8097/.

31. A. A. Victor, and E. G. Babatunde, "Motivation and effective performance of academic staff in higher education (case study of Adekunle Ajasin University, Ondo State, Nigeria)," International Journal of Innovation and Research in Educational Sciences, 1(2), 2014, pp. 157-163.

32. C. T. Iruonagbe, D. Imhonopi, and M. E. Egharevba, "Higher education in Nigeria and the emergence of private universities," International Journal of Education and Research, 3(2), 2015, pp. 49-64.

33. G. M. Akinyemi, and N. Z. Abiddin, "Quality administration and management in higher education in Nigeria: Implications for human resource development," International Education Studies, 6(4), 2013, pp. 225-235.

34. V. Gupta, U. A. Agarwal, and N. Khatri, "The relationships between perceived organizational support affective commitment, psychological contract breach, organizational citizenship behaviour and work engagement," Journal of Advanced Nursing, 72(11), 2016, pp. 2806-2817

35. M. M. Suazo, and W. H. Turnley, "Perceived organizational support as a mediator of the relations between individual differences and psychological contract breach," Journal of Managerial Psychology, 25(6), 2010, pp. 620-648.

36. T. Dulac, J. A. Coyle-Shapiro, D. J. Henderson, and S. J. Wayne, "Not all responses to breach are the same: The interconnection of social exchange and psychological contract processes in organizations," Academy of 
Management Journal, 51(6), 2008, pp. 1079-1098.

37. U. Aggarwal, and S. Bhargava, "Predictors and outcomes of relational and transactional psychological contract," Psychological Studies, 55(3), 2010, pp. 195-207.

38. S. D. Montes, and P. G. Irving, "Disentangling the effects of promised and delivered inducements: Relational and transactional contract elements and the mediating role of trust," Journal of Applied Psychology, 93(6), 2008, pp. 1367-1381.

39. J. L. Pearce, and K. Klein, "Are secret proceedings why longer tenured employees trust their organizations least? 2016 , Available: http://sites.uci.edu/jlpearce/files/2016/12/SecrecyTenure OrgTrustJLOSFinal.pdf.

40. N. Conway, and R. B. Briner, "Fifty years of psychological contract research: What do we know and what are the main challenges," International Review of Industrial and Organizational Psychology, 24(71), 2009, pp. 71-131.

41. M. H. Jafri, "Influence of psychological contract breach on organizational citizenship behaviour and trust," Psychological Studies, 57(1), 2012, pp. 29-36.

42. V. Cassar, S. C. Buttigieg, and R. B. Briner, "Causal explanations of psychological contract breach characteristics," Psychologist-Manager Journal, 16(2), 2013, pp. 85-106.

43. R. Eisenberger, and F. Stinglhamber, Perceived Organizational Support: Fostering Enthusiastic and Productive Employees. Washington DC: American Psychological Association 2011.

44. L. M. Shore, and T. H. Shore, "Perceived organizational support and organizational justice," in Organizational Politics, Justice and Support: Managing the Social Climate in the Work Place, R. Cropanzano and M Kacmar, Eds. Connecticut: Quorum, 1995, pp. 149-164.

45. R. Eisenberger, L. Rhoades, and J. Cameron, "Does pay for performance increase or decrease perceived selfdetermination and intrinsic motivation?" Journal of Personality and Social Psychology, 77(5), 1999, pp. 1026-1040.

46. J. Coyle-Shapiro, and L. Kessler, "Consequences of the psychological contract for the employment relationship: A large scale survey," Journal of Management Studies, 37(7), 2000, pp. 903-930.

47. S. J. Wayne, L. M. Shore, and R. C. Liden, "Perceived organizational support and leader-member exchange: A social exchange perspective," Academy of Management Journal, 40(1), 1997, pp. 82-111.

48. C. Kiewitz, S. L. Restubog, T. Zagenczyk, and W. Hochwarter, "The interactive effects of psychological contract breachand organizational politics on perceived organizational support: Evidence from two longitudinal studies," Journal of Management Studies, 46(5), 2009, pp. 806-834.

49. T. Islam, M. M. Khan, F. N. Khawaja, and Z. Ahmad, 'Nurses' reciprocation of perceived organizational support: The moderating role of psychological contract breach," International Journal of Human Rights in Healthcare, 10(2), 2017, pp. 123-131.

50. A. G. Tekleab, R. Takeuchi, and M. S. Taylor, "Extending the chain of relationships among organizational justice, social exchange, and employee reactions: The role of contract violations," Academy of Management Journal, 48(1), 2005, pp. 146-157.

51. T. J. Zagenczyk, R. Gibney, W. T. Few, and K. L. Scott, "Psychological contracts and organizational identification: The mediating effect of perceived organizational support," Journal of Labor Research, 32(3), 2011, pp. 254-281.
52. S. L. Robinson, "Trust and breach of the psychologica contract," Administrative Science Quarterly, 41(4), 1996, pp. 574-599.

53. J. J. Lavelle, D. E. Rupp, and J. Brockner, "Taking a multifoci approach to the study of justice, social exchange, and citizenship behavior: The target similarity model," Journal of Management, 33(6), 2007, pp. 841 866.

54. P. Paillé, and N. Raineri, "Trust in the context of psychological contract breach: Implications for environmental sustainability," Journal of Environmental Psychology, 45, 2016, pp. 210-220.

55. N. Conway, and R. B. Briner, Understanding Psychological Contracts at Work. A Critical Evaluation of Theory and Research. England: Oxford University Press, 2005.

56. J. A. Coyle-Shapiro, and N. Conway, "The employment relationship through the lens of social exchange," in J. A Coyle-Shapiro, L. M. Shore, S. M. Taylor and L. Tetrick, Eds. The Employment Relationship: Examining Psychological and Contextual Perspectives, England: Oxford University Press, 2004, pp. 5-28.

57. S. D. Pugh, D. P. Skarlicki, and B. S. Passell, "After the fall: Layoff victims' trust and cynicism in re-employment," Journal of Occupational and Organizational Psychology, 76(2), 2003, pp. 201-212.

58. R. V. Krejcie, and D. W. Morgan, "Determining sample size for research activities," Educational and Psychological Measurement, 30(3), 1970, pp. 607-661. 